\title{
Sporcular Tarafından Algılanan Antrenör Davranışlarının Bazı Değişkenlere Göre İncelenmesi*
}

\author{
Investigation of the Perceived Coaching Behaviors by the Athletes \\ According to Some Variables*
}

Belemir ÇíK $K^{* *}$
Veysel KÜÇÜK

Öz

Sosyal ve dinamik bir yapıya sahip olan spor ortamı temel olarak antrenör, sporcu ve antrenman ortamındaki ilişkiler örüntüsünden meydana gelmektedir. Bu çalışmanın amacı 2018-2019 sezonunda Türkiye Basketbol Gençler Ligi ( BGL)'nde görev alan sporcular tarafından algılanan antrenör davranışlarının bazı değişkenlere göre incelenmesidir. Araştırmanın evrenini, BGL'de lisanslı olarak görev alan 247 sporcu oluşturmaktadır. Bu araştırmaya ise, BGL'de görev alan 207 sporcu katılmıştır. Veri toplama araçları olarak Kişisel Bilgi Formu, 47 madde ve 7 alt boyuttan oluşan (antrenman ve kondisyon, teknik beceri öğretimi, zihinsel hazırlık, hedef belirleme, yarışma stratejileri, olumlu antrenör davranışları, olumsuz antrenör davranışları) “Sporcular İçin Antrenör Davranışlarını Değerlendirme Ölçeği (SADDÖ)” kullanılmıştır. Verilerin analizinde SPSS.22 paket programı kullanılmış, bulgular Tek Yönlü Varyans Analizi (ANOVA), Çok Yönlü Varyans Analizi (MANOVA) ve Tamhane's T2 testleri ile incelenmiştir. Elde edilen bulgulara göre; sporcular tarafından algılanan antrenör davranışlarında, aynı antrenörle çalışma süresine göre fiziksel antrenman ve kondisyon, teknik beceri, hedef belirleme, zihinsel hazırlık ve yarışma stratejileri alt boyutlarında istatistiksel olarak anlamlı bir fark bulunurken $(\mathrm{p}<0.05)$, sporcuların basketbol geçmişine ve antrenörlerin yaşına göre anlamlı bir fark bulunamamıştır $(\mathrm{p}>0.05)$. Sporcuların algısına göre en düşük ortalama puana sahip antrenör davranışlarının zihinsel hazırlık ve hedef belirleme çıkması, antrenörlerin sporcu performansının mental boyutuyla ilgili kendilerini geliştirmeleri gerektiği sonucunu göstermektedir.

Anahtar Kelimeler: Sporcu Algısı, Antrenör Davranışı, Basketbol.

\footnotetext{
* Bu çalışma "Sporcular tarafından algılanan antrenör davranışlarının antrenörlerin yeterliğiyle ilişkisinin incelenmesi." başlıklı yüksek lisans tezinden üretilmiştir. Marmara Üniversitesi, Sağlık Bilimleri Enstitüsü. Yıl: 2019. Belemir Çik.

** Yüksek Lisans, Marmara Üniversitesi, Sağlık Bilimleri Enstitüsü, ck.belemir@gmail.com

*** Doç. Dr. Marmara Üniversitesi, Spor Bilimleri Fakültesi, veysel.kucuk@marmara.edu.tr
}

Geliş tarihi: 12.2.2019, Kabul tarihi: 28.05.2019 


\begin{abstract}
The sporting environment, which has a social and dynamic structure, mainly consist of relationship pattern of the coach, the athlete and the training environment. The aim of this study to examine the perceived coaching behaviors by athletes in Turkey Basketball Youth League according to some variables. Target population of the study is consist of licensed involved 247 athletes in Turkey Youth Basketball League. The sample of the study is consist of 207 athletes playing in Turkey Youth Basketball League. Personal Information Forms, "Coaching Behavior Scale for Sport (CBS-S)", which consists of 47 items under seven subscales (training and conditioning, technical skills teaching, mental preparation, goal setting, competition strategies, positive coach behavior, negative coach behavior) were used as a data collection tools. By using SPSS.22 the findings were analyzed through One-way ANOVA, Multivariate ANOVA (MANOVA) and Tamhane's T2 tests. Results show that, there were a significant difference between training and conditioning, mental preparation, goal setting and competition strategies subscales of perceived coaching behaviors according to training time with the same $\operatorname{coach}(\mathrm{p}<0.05)$. However, the difference between perceived coaching behaviors according to athletes' background and age of the coaches were not statistically significant $(\mathrm{p}>0.05)$. According to the perception of the athletes with the lowest average score, mental preparation and goal setting of coach behaviors show that the coaches need to develop themselves about the mental part of the athlete performance.
\end{abstract}

Keywords: Athlete Perception, Coaching Behavior, Basketball.

\title{
GiRiş
}

Günümüzde antrenör davranışları ve yeterliğinin spordan keyif alma ve performans gelişimini etkileyen önemli faktörlerden bazıları olduğu söylenebilir. Sporcular ve antrenörler büyük ölçüde birbirlerine bağımlıdırlar ve aralarındaki etkileşim her zaman performansı belirleyici bir unsur olarak görülmüştür (Toros ve Duvan, 2011). Antrenör, sporcu ve antrenman ortamı arasındaki karmaşık örüntüyü açıklamak için yapılan çalışmalar sporcular tarafından antrenör davranışlarının sporcunun gelişimini doğrudan etkilediğini göstermektedir (Chelladurai, 1984; Smoll ve Smith, 1984; Côté ve ark., 1995). Antrenörlerin grup üyelerini etkileme yeteneği, gerek antrenör sporcu iletişiminde, gerekse istendik motivasyon düzeyine ulaşmada ve öğretilmeye çalışılan koordinatif, teknik, taktik ve psikolojik becerilerde açıkça ortaya çıkmaktadır (Konter, 1996). Bu sebeple, hangi tipteki antrenör davranışlarının sporcuların psikolojik deneyimleriyle nasıl bir ilişkide olduğunun araştırılması gerekmektedir (Price ve Weiss, 2000). Günümüze kadar gelen süreçte antrenörlerle ilgili yapılan araştırmaların birçoğunda takıma liderlik eden antrenörlerin yönetsel açıdan takıma sağladıkları faydalar kategorize edilerek antrenörlerin temel liderlik özellikleri ortaya konmaya çalışılmaktadır (Akkuş, 2014).

Literatürde yer alan antrenörlerin liderlik yönelimlerini belirlemeye çalışan modeller dikkate alındığında, 'Sporda Çok Boyutlu Liderlik' (Chelladurai, 1990; 2007) ve 'Arabulucu Liderlik' (Smoll ve Smith, 1989) gibi sporcunun gelişimini doğrudan etkilediğini gösteren modeller ön plana çlkmaktadır. Geliştirilen bu modeller birbirlerini desteklemelerine, benzer boyutları içermelerine rağmen antrenörlük sürecini kapsayacak bir ana hat oluşturmada yetersiz kaldıklarından, Côté (1998) farklı bir bakış açısı ile yaklaşarak geliştirdiği 'Antrenörlük Modeli' ile bu ihtiyacı karşılamaya çalışmıştır. Antrenörlük Modelinin kuramsal temelini üst düzey antrenörlerin davranışlarını uzman 
sistem yaklaşımı bakış açısı ile ele alınması oluşturmuş ve antrenörlük sürecinin çevresel ve davranışsal öğelerden oluştuğu bulunmuştur. Antrenörlük sürecinin çevresel öğeleri; antrenörün kişisel özellikleri, takımın veya sporcuların kişilik özellikleri ve antrenman ortamı olarak belirlenirken, antrenörlüğün davranışsal süreçleri; yarışma, organizasyon, antrenman olarak belirlenmiştir (Yapar ve İnce, 2014).

Antrenör davranışlarıyla yapılan ilk çalışmalar antrenörlüğün öğretim rollerinin vurgulandığı Tharp ve Gallimore (1976)'un usta öğretmen, basketbol koçu John Wooden’ın antrenman çalışmalarını incelemeleriyle başlamıştır. Araştırmacıların 'Antrenör Davranışları Kayıt Formu’nu (Coaching Behavior Recording Form) kullanarak davranışlarını kodladıkları John Wooden’ın sporcularına en çok ne yapmaya ve nasıl yapmaya ihtiyaçları olduğu hakkında (\%50.3) yönergeler, ikinci olaraksa saldırgan oynamakla ilgili motivasyonu arttırıcı yönergeler (\%12.7) verdiğini gözlemledikleri çalışmalar antrenör davranışları araştırmaları için bir dönüm noktası olarak kabul edilmektedir ( Yardley ve ark., 1999).

Antrenör davranışlarıyla ilişkisine bakılan bazı değişkenler literatürde bu çalışmalarla yer almıştır: sporda tükenmişlik (Vealey ve ark., 1998), temel psikolojik ihtiyaçlar (Reinboth ve Duda, 2006), sporcu doyumu (İnce, P., 2006), hedef yönelimi (Toros, 2011), takım sargınlığı (Toros, 2011), özyeterlik (Cengiz ve ark., 2012), yarışma kaygısı (Ledochowski ark., 2012), grup yeterliği (Toros ve Duvan, 2011).

Misasi, Morin ve Kwasnowski (2016)'in üniversitelerin 1. ve 2. Liglerinde yer alan antrenörlerin ve sporcuların antrenör-sporcu ilişkisinin kişiler arası yönlerini ve antrenör algılarını araştırdıkları çalışmada, antrenör-sporcu ilişkisinde gruplar arasında anlamlı bir farklılık bulunamazken, sporcular tarafından algılanan antrenör davranışlarının yarışma stratejileri, olumlu antrenör davranışı ve olumsuz antrenör davranışı alt boyutlarında istatistiksel olarak anlamlı bir fark bulunmuştur.

Başka bir çalışmada yaşları 10 ile 18 arasında değişen toplam $312 \mathrm{kız}$ ve erkek yüzücülerde algılanan antrenörlük davranışı ile sporcuların kendi spor yeteneklerini ve motivasyon türlerini algılamaları arasındaki ilişki üzerinde çalışan Black ve Weiss (1992), başarılı performansların ardından daha çok geri bildirimde bulunan, başarısız performansların ardındansa geri bildirim verme amaçlı teknik yönergelerle sık sık cesaret veren antrenörlerin sporcuları en yüksek özgüven ve motivasyonpuanlarına sahip olurken, bunun tam tersi eğilimde olan antrenörlerin sporcularının en düşük düzeyde motivasyon puanlarına sahip olduğu bulgularına ulaşmışlardır (Barut, 2018).

Son otuz yıl içerisindeki araştırmalarda bir lider olarak antrenörün ve spora katılan bireylerin durumsal ve demografik özelliklerine liderlerin davranışlarının sonuçlarına, liderlerin davranışlarının sporcularının performanslarını nasıl etkilediğini anlamaya ve sporcuların memnuniyeti üzerine odaklanmıştır (Martin ve Barnes, 1999; Baker ve ark., 2003; Amorose, 2007; Gillet ve ark., 2010).

Yukarıda ifade edilen bilgiler doğrultusunda araştırmamızın amacı; 2018-2019 sezonunda Türkiye Basketbol Gençler Ligi'nde görev alan sporcular tarafından algılanan antrenördavranışlarını belirlemek, sporcuların antrenör algılarında etkili olabileceği düşünülen bazı değişkenlerin analizini yapmak ve çözüm önerileri sunmaktır. 


\section{GEREÇ VE YÖNTEM}

\section{Çalışma Grubu}

Araştırmanın evrenini, Türkiye Basketbol Gençler Liginde (BGL) lisanslı olarak görev alan 247 sporcu oluşturmaktadır. Bu araştırmaya ise, BGL'de görev alan 207 sporcu katılmıştır. Araştırma evreni sadece BGL sporcuları ve antrenörleri olarak belirlendiğinden örnekleme yöntemi olarak, olasılıksız örnekleme yöntemlerinden elverişli örnekleme yöntemi seçilmiştir.

\section{Veri Toplama Araçları}

Araştırmaya katılan sporcuların demografik bilgileri öğrenmek amacıyla araştırmacı tarafından geliştirilen kişisel bilgi formu; sporcuların algıladıkları antrenör davranışlarını ölçmek amacıyla Côté ve arkadaşları tarafından (1999) geliştirilen ve özgün adı "Coaching Behavior Scale for Sport (CBS-S)" olan, Yapar ve İnce (2014) tarafından 14-22 yaş aralığındaki farklı branş sporcularıyla Türkçe uyarlaması yapılan, 47 madde 7 alt boyuttan oluşan ( antrenman ve kondisyon, teknik beceri öğretimi, zihinsel hazırlık, hedef belirleme, yarışma stratejileri, olumlu antrenör davranışları, olumsuz antrenör davranışları) oluşan Sporcular İçin Antrenör Davranışlarını Değerlendirme Ölçeği (SADDÖ) kullanılmıştır.

\section{Verilerin Analizi}

Sporcuların basketbol oynama geçmişi, aynı antrenörle çalışma süresive antrenörlerinin yaşları araştırmanın bağımsız değişkenlerini oluştururken, bağımlı değişkenini örneklem grubunun SADDÖ puanları oluşturmuştur. Araştırmada elde edilen veriler SPSS.22 paket programına aktarılmış, tüm istatistiki işlemlerdeki analizler aynı program üzerinde gerçekleştirilmiştir. Tanımlayıcı istatistiklerin hesaplanmasının yanı sıra Tek Yönlü Varyans Analizi (ANOVA), Çok Yönlü Varyans Analizi (MANOVA), Pillai’s Trace Test ve Tamhane T2 olmak üzere farklı istatistik tekniklerinden yararlanılmıştır.

\section{BULGULAR}

Tablo 1. Sporculara İlişkin Demografik Özellikler.

\begin{tabular}{l|l|l|l|l|l}
\hline Yaş & $\mathbf{1 5 - 1 6}$ & $\mathbf{1 7 - 1 8}$ & $\mathbf{1 9 - 2 1}$ & & \\
\hline & $31(\% 15)$ & $156(\% 75,4)$ & $20(\% 9,7)$ & & \\
\hline Eğitim & Lise & Üniversite & & & \\
\hline & $187(\% 90,3)$ & $20(\% 9,7)$ & & & \\
\hline Mevki & $\mathbf{1}$ & $\mathbf{2}$ & $\mathbf{3}$ & $\mathbf{4}$ & $\mathbf{5}$ \\
\hline & $45(\% 21,7)$ & $40(\% 19,3)$ & $40(\% 19,3)$ & $41(\% 19,8)$ & $41(\% 19,8)$ \\
\hline Basketbol Geçmişi & $\mathbf{1 - 2}$ yll & $\mathbf{3 - 6}$ yll & $\mathbf{7 - 9}$ yl & $\mathbf{1 0}$ yl ve üzeri & \\
\hline & $3(\% 1,4)$ & $66(\% 31,9)$ & $98(\% 47,3)$ & $40(\% 19,3)$ & \\
\hline
\end{tabular}




\begin{tabular}{l|l|l|l|l|l}
\hline Millilik & Evet & Hayır & & & \\
\hline & 63 (\%30,4) & $144(\% 69,6)$ & & & \\
\hline Baş Antrenörle Çalışma Süresi & 6 aydan az & 6ay-1yıl & 2-4yıl & 5 yıl ve + & \\
\hline & $39(\% 18,8)$ & $6(\% 41,5)$ & $70(\% 33,8)$ & $12(\% 5,8)$ & \\
\hline Yrd. Antrenörle Çalışma Süresi & 6 aydan az & 6ay-1yıl & 2-4yıl & $\mathbf{5}$ yll ve + & \\
\hline & $38(\% 18,4)$ & $88(\% 42,5)$ & $77(\% 37,2)$ & $4(\% 1,9)$ &
\end{tabular}

Yaş ve eğitim dağılımlarına bakıldığında \%75,4'ünün 17-18 yaşlarında olduğunu ve \%90,3'ünün lisede eğitim aldığı görülmüştür. Sporcuların basketbol geçmişlerine bakıldığında \%47,3’ünün 7-9 yıldır basketbol oynadığı ve \%30,4’ünün milli takımda görev aldıkları bilgilerine ulaşılmıştır. Aynı antrenörle çalışma sürelerine bakıldığında baş antrenörler için de $(\% 41,5)$ yardımcı antrenörler için de (\% 42,5) ‘6ay-1yıl' aralığının çoğunlukta olduğu görülmüştür.

Tablo 2.Sporcular Tarafından Algılanan Antrenör Davranışlarına İlişkin Ortalama, Standart Sapma ve Güvenilirlik Değerleri

\begin{tabular}{llll}
\hline Alt Boyutlar & $\overline{\mathbf{x}}$ & ss & $\mathbf{a}$ \\
\hline F.Antrenman ve Kondisyon & 5.15 & 1.31 & .90 \\
Teknik Beceri Öğretimi & $\mathbf{5 . 5 0}$ & $\mathbf{1 . 5 2}$ & $\mathbf{. 9 7}$ \\
Zihinsel Hazırlık & $\mathbf{4 . 7 8}$ & $\mathbf{1 . 8 2}$ & $\mathbf{. 9 6}$ \\
Hedef Belirleme & $\mathbf{4 . 8 0}$ & $\mathbf{1 . 7 0}$ & $\mathbf{. 9 5}$ \\
Yarı̧ma Stratejileri & 5.03 & 1.63 & $\mathbf{. 9 4}$ \\
Olumlu Antrenör Davranı̧̧ı & 5.44 & 1.59 & $\mathbf{. 9 4}$ \\
Olumsuz Antrenör Davranı̧ı1 & 4.44 & 1.21 & $\mathbf{. 7 5}$ \\
\hline
\end{tabular}

Sporcular tarafindan algılanan antrenör davranışlarına bakıldığında en yüksek ortalama değer teknik beceri öğretimi olurken ( $5.50 \pm 1.52$ ), en düşük ortalama değerleri olumsuz antrenör davranış1 $(4.44 \pm 1.21)$, zihinsel hazırlık $(\mathrm{x}=4.78 \pm 1.82)$ ve hedef belirleme $(4.80 \pm 1.70)$ alt boyutlarında görülmektedir. 'SADDÖ' için olumsuz antrenör davranışını ölçen 7 soru ters çevrilerek puanlamaya dahil edilmiştir. Yapılan güvenilirlik analizi sonucunda ölçeğin tüm alt boyutları sosyal bilimlerde makul kabul edilen .60 ve yukarısı Cronbach’s Alpha değerlerini karşılamaktadır.

Tablo 3. Sporcular Tarafından Algılanan Antrenör Davranışlarının Sporcuların Basketbol Oynama Geçmişlerine Göre Karşılaştırılması

\begin{tabular}{|c|c|c|c|c|c|c|c|c|c|c|}
\hline \multirow[t]{2}{*}{ Alt boyutlar } & \multicolumn{2}{|c|}{$1-2$ yil } & \multicolumn{2}{|c|}{ 3-6 yil } & \multicolumn{2}{|c|}{ 7-9 yil } & \multicolumn{2}{|c|}{$10 \mathrm{yll}+$} & \multirow[t]{2}{*}{$\mathrm{F}$} & \multirow[t]{2}{*}{$\mathbf{P}$} \\
\hline & $\bar{x}$ & ss & $\bar{x}$ & ss & $\bar{x}$ & ss & $\bar{x}$ & ss & & \\
\hline F.Antrenman & 5.71 & 1.36 & 5.05 & 1.38 & 5.25 & 1.95 & 5.02 & 1.48 & .37 & .78 \\
\hline Teknik Beceri & 6.92 & .14 & 5.28 & 1.67 & 5.54 & 1.36 & 5.67 & 1.65 & 1.96 & .12 \\
\hline Zihinsel Hazırlık & 6.33 & .83 & 4.60 & 1.84 & 4.82 & 1.74 & 4.88 & 2.01 & 1.51 & .21 \\
\hline Hedef Belirleme & 5.83 & 1.01 & 4.67 & 1.74 & 4.82 & 1.60 & 4.91 & 1.90 & .96 & .42 \\
\hline YarışmaStratejisi & 4.76 & 2.22 & 5.01 & 1.73 & 5.02 & 1.54 & 5.10 & 1.71 & .25 & .86 \\
\hline
\end{tabular}




\begin{tabular}{lllllllllll} 
Olumlu Antrenör & 6.44 & .96 & 5.18 & 1.71 & 5.49 & 1.52 & 5.68 & 1.57 & .45 & .72 \\
OlumsuzAntrenör & $\mathbf{4 . 0 0}$ & $\mathbf{1 . 7 7}$ & $\mathbf{4 . 5 5}$ & $\mathbf{1 . 2 0}$ & $\mathbf{4 . 3 3}$ & $\mathbf{1 . 1 4}$ & $\mathbf{4 . 5 8}$ & $\mathbf{1 . 3 7}$ & $\mathbf{1 . 1 8}$ & $\mathbf{. 3 2}$ \\
\hline
\end{tabular}
${ }^{*} \mathrm{p}<0.05$

Sporcular tarafından algılanan antrenör davranışları alt boyutlarında basketbol oynama geçmişlerine göre değişmeksizin en yüksek ortalama değerler teknik beceri öğretimi alt boyutundayken 1-2 yıl (6.92 \pm 0.14$)$, 3-6 yıl (5.28 \pm 1.67$)$, 7-9yıl (5.54 \pm 1.36$)$, 10 yıl ve üzeri $(5.67 \pm 1.65)$ en düşük değerler

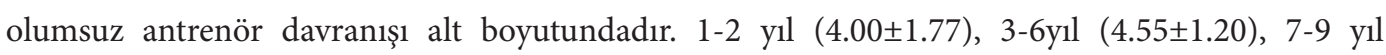
(4.33 \pm 1.14$)$, 10 y1l ve üzeri $(4.58 \pm 1.37)$.

MANOVA analiz sonuçlarına göre sporcular tarafından algılanan antrenör davranışlarının alt boyutlarında sporcuların basketbol oynama geçmişlerine göre istatistiksel olarak anlamlı bir fark yoktur ( $\mathrm{p}>0.05)$.

Tablo 4. Sporcular Tarafından Algılanan Antrenör Davranışlarının Aynı Antrenörle Çalışma Sürelerine Göre Karşılaştırılması

\begin{tabular}{|c|c|c|c|c|c|c|c|c|c|c|}
\hline \multirow[t]{2}{*}{ Alt boyutlar } & \multicolumn{2}{|c|}{6 aydan az } & \multicolumn{2}{|c|}{ 6ay-1yıl } & \multicolumn{2}{|c|}{$2-4$ yll } & \multicolumn{2}{|c|}{$5 \mathrm{yll}+$} & \multirow[t]{2}{*}{$\mathrm{F}$} & \multirow[t]{2}{*}{$\mathbf{P}$} \\
\hline & $\bar{x}$ & ss & $\bar{x}$ & ss & $\bar{x}$ & ss & $\bar{x}$ & ss & & \\
\hline F.Antrenman & 5.39 & 1.25 & 5.42 & 1.04 & 4.75 & 1.50 & 4.73 & 1.58 & 4.47 & $0.01^{\star}$ \\
\hline Teknik Beceri & 6.20 & 1.17 & 5.73 & 1.16 & 4.95 & 1.75 & 4.77 & 2.06 & 8.20 & $0.00^{*}$ \\
\hline Zihinsel Hazırlık & 5.06 & 1.74 & 5.15 & 1.69 & 4.26 & 1.89 & 4.30 & 1.93 & 3.86 & $0.01^{\star}$ \\
\hline Hedef Belirleme & 5.12 & 1.55 & 5.10 & 1.49 & 4.29 & 1.85 & 4.71 & 2.05 & 3.56 & $0.02^{*}$ \\
\hline YarışmaStratejisi & 5.31 & 1.61 & 5.30 & 1.45 & 4.64 & 1.75 & 4.45 & 1.75 & 3.13 & $0.03^{*}$ \\
\hline Olumlu Antrenör & 5.66 & 1.54 & 5.60 & 1.28 & 5.17 & 1.90 & 5.13 & 1.92 & 1.34 & 0.25 \\
\hline OlumsuzAntrenör & 455 & 1.21 & 4.56 & 1.16 & 4.26 & 1.24 & 4.31 & 1.40 & 0.91 & 0.44 \\
\hline
\end{tabular}

${ }^{*} \mathrm{p}<0.05$

Tablo 4.de verilen bulgulara göre, en yüksek ortalama değer teknik beceri öğretimi alt boyutunda 6

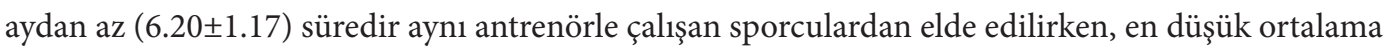

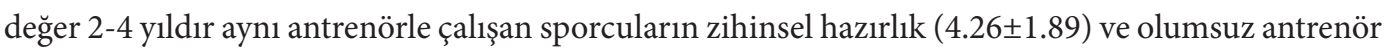

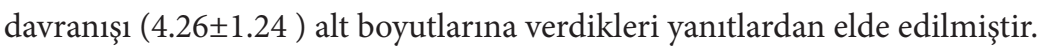

MANOVA Pillai's Trace Test sonucuna göre aynı antrenörle çalışma süreleri ile sporcular tarafından algılanan antrenör davranışları arasında anlamlı bir fark vardır $(\mathrm{p}<0.05)$. Fiziksel antrenman ve kondisyon alt boyutunda 6 aydan az süredir aynı antrenörle çalışan sporcularla 2-4 yıldır aynı antrenörle çalışan sporcular arasında, teknik beceri öğretimi alt boyutunda 2-4 yıldır aynı antrenörle çalışan sporcularla 6 ayda az ve 6 ay-1yıl süreyle aynı antrenörle çalışan sporcular arasında ve 6 ay1yıl ve 2-4yıl süreleriyle aynı antrenörle çalışan sporcu grupları arasında hedef belirleme, zihinsel hazırlık ve yarışma stratejileri alt boyutlarında istatistiksel olarak anlamlı fark olduğu bulgularına ulaşılmıştır $(\mathrm{p}<0.05)$. 
Tablo 5. Sporcular Tarafından Algılanan Olumlu ve Olumsuz Antrenör Davranışlarının Antrenörlerin Yaşlarına Göre Karşılaştırılması

\begin{tabular}{|c|c|c|c|c|c|}
\hline $\begin{array}{l}\text { Yaş } \\
\text { Yaş }\end{array}$ & $\mathbf{N}$ & \multicolumn{2}{|c|}{$\begin{array}{l}\text { Olumlu Antrenör } \\
\text { Davranışları } \\
\bar{x} \text { ss }\end{array}$} & \multicolumn{2}{|c|}{ 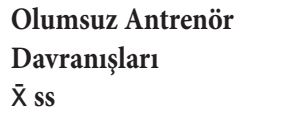 } \\
\hline $18-26$ & 12 & 6.60 & 0.75 & 4.87 & 1.32 \\
\hline $27-35$ & 29 & 5.64 & 1.41 & 4.60 & 1.22 \\
\hline $36-44$ & 16 & 5.96 & 1.51 & 4.33 & 1.40 \\
\hline $45-53$ & 3 & 6.44 & 0.69 & 5.58 & 0.76 \\
\hline
\end{tabular}

Tablo 5.de verilen bulgulara göre, sporcular tarafından algılanan antrenör davranışlarının olumlu ve olumsuz antrenör davranışı alt boyutlarında her yaş aralığ 1 için p değeri 0.05 'den büyük olduğundan, antrenörlerin yaşının sporcuların olumlu ve olumsuz antrenör davranışlarını algılamada istatistiksel olarak anlamlı bir etkisi olmadığı bulgularına ulaşılmıştır. Sporcular tarafından algılanan olumlu antrenör davranışlarında en yüksek ortalama değere $(\bar{X}=6.60 \pm 0.75)$ yaşları 18-26 arasında değişen antrenörlerde ulaşılırken, olumsuz antrenör davranışlarında en yüksek ortalama değere ( $\overline{\mathrm{X}}=5.58$ \pm 0.76 ) yaşları 45-53 arasında değişen antrenörlerde ulaşılmaktadır.

\section{TARTIŞMA VE SONUÇ}

Bu çalışma, sporcular tarafından algılanan antrenör davranışlarının bazı değişkenlere göre incelemek üzere Türkiye Basketbol Gençler Ligi (BGL)'nde görev alan sporcu ve antrenörleri üzerine yapılan nicel bir araştırmayı kapsamaktadır. Yapılan bu araştırmanın sonucuna göre bu ligdeki sporcuların büyük çoğunluğunun 17-18 yaşlarında lisede eğitim gören ve yüzde \% 30,4'ünün milli takımlarda görev almış sporculardan oluştuğu görülmektedir. Sporcuların aynı antrenörlerle en fazla 6ay-1yıl süreyle birlikte çalışıyor oldukları ve bu ligde yer alan antrenörlerin çoğunlukla 27-35 yaş aralığında değişen 4. ve 3. Kademe antrenörlük belgesine sahip antrenörler oldukları bilgilerine ulaşılmıştır.

Araştırmanın birinci denencesi ile ilgili analizlerin sonuçlarına göre, sporcular tarafından algılanan antrenör davranışlarının alt boyutlarında sporcuların basketbol oynama geçmişlerine göre istatistiksel olarak anlamlı bir fark bulunamamıştır; ancak teknik beceri öğretimi alt boyutuna 10 yıl ve üzeri basketbol geçmişi olan sporcuların 3-6 yıl ve 7-9 yıl basketbol geçmişine sahip sporculara göre daha yüksek ortalama değer elde ettikleri bulunmuştur. Ayrıca 10 yıl ve daha fazla süredir basketbol oynayan sporcuların olumsuz antrenör davranışı alt boyutunda en düşük ortalama değerlere sahip olduğu bulgusuna da ulaşılmıştır. Bu çalışma, 22 yıl ve üzeri spor geçmişi olan sporcuların 7 yıl ve altı spor geçmişi olan sporculara göre antrenörlerinin iletişim becerisini daha yüksek seviyede algıladıkları sonucuna ulaşan Ateş, Yıldız ve Yıldız (2018)'ın profesyonel basketbol ve voleybolcuların antrenör iletişim beceri düzeyleri algısı hakkında 235 sporcuyla gerçekleştirdikleri çalışmayı desteklemektedir. 
Araştırmanın ikinci denencesi ile ilgili analizlerin sonuçlarına bakıldığında, sporcular tarafından algılanan antrenör davranışları aynı antrenörle çalışma sürelerine göre fiziksel antrenman ve kondisyon alt boyutunda 6 aydan az süredir aynı antrenörle çalışan sporcularla 2-4 yıldır aynı antrenörle çalş̧an sporcular arasında ve teknik beceri öğretimi alt boyutunda 2-4 yıldır aynı antrenörle çalışan sporcularla 6 ayda az ve 6 ay-1yıl süreyle aynı antrenörle çalışan sporcular arasında istatistiksel olarak anlamlı fark bulunmuştur. 6 ay-1yıl ile 2-4yıl süreleriyle aynı antrenörle çalışan sporcu grupları arasında hedef belirleme, zihinsel hazırlık ve yarışma stratejileri alt boyutlarında istatistiksel olarak anlamlı fark olduğu bulgularına ulaşılmıştır. Genel olarak tüm alt boyutlarda 6 aydan az ve 6ay-1yıl süreyle aynı antrenörle çalışan sporcuların ortalamaları 2-4 yıl ve 5 yıl ve üzeri süreyle aynı antrenörle çalışan sporculardan daha fazla bulunması birkaç yıldır var olan bu ligte oyuncuların sezondan sezona değişmesi ve en fazla 6ay-1yıl süreyle aynı antrenörle çalışan sporcuların örneklemi oluşturasına bağlanabilir. Aynı antrenörle çalışma süresi arttıkça sporcular tarafından algılanan olumlu antrenör davranışının anlamlı olarak farklılaşmamasından yola çıarak bu çalışma Abakay ve Kuru (2013)'nun spor yapma yılı ve aynı antrenörle çalışma süresi arttıkça ve Selağzı ve Çepikkurt (2014)'un aynı antrenörle çalışma süresi arttıkça sporcular tarafından algılanan iletişim düzeyinin de arttığını gösteren bulgularla çelişmektedir.

Bunun yanında çalışma sonucunda sporcular tarafından algılanan antrenör davranışlarını değerlendiren ölçeğin pozitif davranışları ölçen 6 alt boyutundan en düşük ortalama puana sahip olanların zihinsel hazırlık ve hedef belirleme alt boyutları olarak belirlenmesi antrenörlerin sporcu performansının mental boyutuyla ilgili kendilerini geliştirmeleri gerektiği yorumu yapılabilir.

Araştırmanınüçüncüdenencesiileilgilianalizlerinsonuçlarınabakıldığında, sporcular tarafından algılanan olumlu antrenör davranışlarında en yüksek ortalama değere yaşları 18-25 arasında değişen antrenörlerde ulaşllırken, olumsuz antrenör davranışlarında en yüksek ortalama yaşları 45-53 arasında değişen antrenörlerde ulaşılmaktadır.Ayrıca antrenörlerin yaşlarının sporcuların olumlu ve olumsuz antrenör davranışlarını algılamasında istatistiksel olarak anlamlı bir etkisi olmadığı bulgusuna ulaşılmıştır. Bu bulgu, Başer (2009)'un Türkiye Basketbol Erkekler 1.Ligi’nde görev yapan sporcuların, antrenörleri ile ilgili algıladıkları liderlik davranışlarının ve antrenörlerin gerçek liderlik davranışlarının belirlenmesi amacıyla gerçekleştirdiği çalışmanın yaşa göre sporcular tarafından algılanan lider özellikleri farklılık göstermemektedir bulgusunu desteklemektedir. Ermiş ve ark. (2017) tarafından değişik branşlarla ilgilenen adelosan sporcuların antrenörlerinin davranışlarını algılama düzeyinin araştırılması amacıyla yaptıkları çalışmada yaşa göre; teknik beceri, hedef belirleme, yarışma stratejisi ve olumsuz antrenör davranışları alt boyutlarında anlamlı farklılıklar tespit edildiği ve adelosan sporcuların antrenörlerinin kendilerine karşı davranışlarını algılama düzeylerinde farklılıklar olduğu bulgusu bizim çalışmamızın bulgularıyla farklılaşmaktadır.

Sonuç olarak, sporcular tarafından algılanan antrenör davranışları sporcunun basketbol geçmişi ve antrenör yaşı kriterlerine göre anlamlı olarak farklılaşmamaktadır, böylelikle araştırmanın birinci ve üçüncü denenceleri reddedilmiştir. Sporcular tarafından algılanan antrenör davranışları aynı antrenörle çalışma süresi değişkenine göre fiziksel antrenman ve kondisyon, zihinsel hazırlık, hedef 
belirleme ve yarışma stratejileri alt boyutlarında istatistiksel olarak anlamlı bir fark olduğu sonucuna ulaşılarak araştırmanın ikinci denencesi kabul edilmiştir.

Bu araştırmada ortaya çıkan sonuçlara göre aşağıdaki öneriler getirilebilir;

- Aynı antrenörle çalışma süresine göre sporcular tarafından algılanan antrenör davranışlarında anlamlı farklılıklar olması bulgusundan yola çıkılarak antrenörlerin çalıştırdıkları sporcu grubuyla birlikte olduğu dönemin uzun vadeli planlanması,

- Sporcular tarafından algılanan antrenör davranışlarında en düşük ortalama değerlerin zihinsel hazırlık ve hedef belirleme alt boyutlarından elde edilmesi bulgusundan yola çıkarak antrenörler için zihinsel hazırlık ve doğru hedef belirleme becerileri başta olmak üzere 'psikolojik becerileri geliştirme’ eğitim programı düzenlenmesi,

- Antrenörler tarafından sporcuların performanslarının yanında kariyer planlamalarına da zaman ayırarak doğru hedef belirleme stratejileriyle ilgili çalışmaların yapılması,

- Antrenörlerin sezon hazırlığı başladığı andan itibaren fiziksel kondisyon ve teknik antrenmanların yanında zihinsel antrenmanların da sezon programına dahil edilmesi önerilmektedir.

\section{KAYNAKLAR}

Abakay, U. \& Kuru, E. (2013). Kadın Futbolcularda Antrenörle İletişim Düzeyi Ve Başarı Motivasyonu İlişkisi. Gaziantep University Journal of Social Sciences, 12(1).

Akkuş, S. (2014). Erkekler Birinci Voleybol Liginde Yer alan Takımların Antrenörlerinin Liderlik Özellikleri ile Sporcuların Bu Konudaki Düşüncelerinin Karşılaştırılması. Gazi Üniversitesi Sağlık Bilimleri Enstitüsü, Yüksek Lisans Tezi, Ankara.

Amorose A. J. (2007) Coaching Effectiveness. In: MS Haggerand NLD Chatzisarantis (Eds), Intrinsic Motivation and Self-Determination in Exercise and Sport. Human Kinetics, Leeds 209 - 227.

Ateş,C., Yıldız, Y. \& Yıldız, K. (2018). Profesyonel Basketbol ve Voleybolcuların Antrenör İletişim Beceri Düzeyleri Algısı ve Sporcuların Kaygı Düzeylerinin Araştırılması. Erciyes İletişim Dergisi, 5(3), 40-52.

Baker, J., Yardley, J. \& Côté J. (2003). Coach behaviors and athlete satisfaction in team and individual sports. International Journal of Sport Psychology, 34, 226-239.

Barut, A., İ. (2018) . Farkl Hedef Yönelimlerine Sahip Unilig Erkek Basketbolcularının Algılanan Liderlik Davranışı ve Antrenör Davranışlarını Değerlendirmelerinin Karşılaştırılması. Mersin Üniversitesi .Yayınlanmş Doktora Tezi, Mersin.

Başer, T. (2009). Türkiye basketbol erkekler 1. Ligi’nde (Beko Basketbol Ligi) Görev Yapan Antrenörlerin Algilanan Liderlik Özellikleri ile Gerçekte Var Olan Liderlik Özelliklerinin İncelenmesi ve Yeni Bir Model Önerisi. Marmara Üniversitesi. Beden Eğitimi ve Spor Anabilim Dalı. Yüksek Lisans Tez, İstanbul

Black, S. J. \& Weiss, M. R. (1992). The relationship among perceived coaching behaviors, perceptions of ability, and motivation in competitive age-group swimmers. Journal of SportandExercise Psychology, 14(3), 309325.

Cengiz, R., Korucu, A. G. \& Abakay, U. (2012). Taekwondo Sporcularının Algıladığı Liderlik Özellikleri İle Öz-Yeterlik Düzeyleri Arasındaki İlişki. E-Journal of New World Sciences Academy, 7(4), 69-78.

Chelladurai, P. (1984). Leadership in Sport. In J.M. Silva, R.S. Weinberg (Eds.) Psychological Foundations of Sport.Champaign, IL; Human Knetics. s. 329-339. 
Chelladurai, P. (1984). Discrepancy between preferences and perceptions of leadership behavior and satisfaction of athletes in varying sports. Journal of sport psychology, 6(1), 27-41.

Côté, J., Salmela, J., H., Trudel, P., Baria, A., Russell, S., J. (1995). The coaching model: A grounded assessment of expertise gymnastic coaches' knowledge. Journal of SportఓExercise Psychology; 17, 1-17.

Côté, J.,Salmela, J. H. \& Russell, S. (1995). The knowledge of high-performance gymnastic coaches: Methodological framework. The Sport Psychologist, 9(1), 65-75.

Ermiş ve ark. (2017). Adelosan Sporculara Göre Antrenör Davranışları. Kesit Akademi Dergisi.3(12), s. 589-599.

Gillet, N., Vallerand R., J, Amoura, S. et al. (2010). Influence of coaches' autonomy support on athletes' motivation and sport performance: a test of the hierarchical model of intrinsic and extrinsic motivation. Psychology of Sport and Exercise; 11,155-116.

İnce, P. (2006). Antrenör Davranışları ve Sporcu Doyumu: Ölçek Geliştirme ve Uyarlama Çalışması.Celal Bayar Üniversitesi. Sporda Psiko-Sosyal Alanlar Bilim Dalı. Yayınlanmış Yüksek Lisans Tezi. Manisa.

Konter, E. (1996). Bir Lider Olarak Antrenör. 1.Basım, İstanbul: Alfa Basım Yayım Dağıtım; 56, 104-105.

Ledochowski, L.,Unterrainer, C., Ruedl, G., Schnitzer, M. \& Kopp, M. (2012).Quality of life, coach behaviour and competitive anxiety in Winter Youth Olympic Games participants. British Journal of Sports Medicine, 46(15), 1044-1047. doi:10.1136/bjsports-2012-091539

Martin, S. B. \& Barnes, K. (1999). Coaching Behavior Questionnaire. Unpublished manual. University of North Texas. Denton.

Misasi, S. P., Morin, G. \& Kwasnowski, L. (2016). Leadership: Athletes and coaches in sport. The Sport Journal, 19.

Price, M., L. ve Weiss, M., R. (2000). Coach burnout, coach behaviors, and athletes' psychological responses: Applying Chelladurai's multidimensional model of leadership. The Sport Psychologist; 14,391-409.

Reinboth, M. \& Duda, J. L. (2006). Perceived motivational climate, need satisfaction and indices of well-being in team sports: A longitudinal perspective. Psychology of Sport and Exercise, 7(3), 269-286.

Selağzı, S. \& Çepikkurt, F. (2015). Antrenör ve Sporcu İletişim Düzeylerinin Belirlenmesi. CBÜ Beden Eğitimi ve Spor Bilimleri Dergisi, 9(1), 11-18.

Smoll F. L. \& Smith, R. E. (1984). Leadership research in youth sports. In J. M. Silva III \& R. S. Weinberg (Eds.), Psychological foundations of sport Champaign, IL: Human Kinetics; s.371-386.

Tharp, R. G. \& Gallimore, R. (1976). What a coach can teach a teacher. Psychology Today, 9(8), 75-78.

Toros, T. (2011). Genç erkek basketbolcularda, turnuva öncesi ve turnuva sonrası sporcuların algıladıkları antrenörlük davranışı, hedef yönelimleri, takım sargınlığı, algılanan motivasyonel iklim ve kolektif yeterlik arasındaki farklılığın analizi. Pamukkale Journal of Sport Sciences, 2(1), 39.

Toros, T. ve Duvan, A. (2011). Eskrimcilerde Algılanan Antrenörlük Davranışı, Kolektif Yeterlik ve Hedef Yönelimleri Arasındaki İlişki. Niğde Üniversitesi Beden Eğitimi Ve Spor Bilimleri Dergisi; 5, 1.

Vealey, R. S., Armstrong, L., Comar, W. \& Greenleaf, C. A. (1998). Influence of perceived coaching behaviors on burnout and competitive anxiety in female college athletes. Journal of AppliedSportPsychology, 10(2), 297-318.

Yapar, A. ve İnce, M. L. (2014). Sporcular İçin Antrenör Davranışlarını Değerlendirme Ölçeğinin Türkçe Uyarlaması (SADDÖ): Geçerlik ve Güvenirlik Çalışması.

Yapar, A. (2016). İki Basketbol Eğitimi Ortamında Antrenman Etkinlikleri, Antrenör Davranışları ve Sporcuların Psikososyal Kazanımlarının Karşılatırılması. Orta Doğu Teknik Üniversitesi. Beden Eğitimi ve Spor Anabilim Dalı. Doktora Tezi, Ankara .

Yardley, J, Côté, J, Hay, J, Sedgwick, W, Baker, J. (1999). An exploratory examination of the Coaching Behaviour Scale for Sport.Avante; 5, 82-92. 
Yılmaz, İ. (2008). Sporcu algıları çerçevesinde farklı spor branşlarındaki antrenörlerin liderlik davranış analizleri ve iletişim beceri düzeyleri. Yayınlanmamış Doktora Tezi, Gazi Üniversitesi Sağlık Bilimleri Enstitüsü, Ankara. 